\title{
Design and selection of triazole-based compounds with high energetic properties and stabilities
}

\author{
GUOZHENG ZHAO*, JIANFENG JIA and HAISHUN WU \\ School of Chemistry and Materials Science, Shanxi Normal University, Linfen, \\ Shanxi, 041004, PR China \\ e-mail: zhaoguozheng99@126.com
}

MS received 31 January 2016; revised 12 April 2016; accepted 25 May 2016

\begin{abstract}
Density functional theory (DFT) was used to study the molecular geometries, electronic structures, heats of formation in gas phase and in condensed phase, energetic properties, and thermal stabilities of triazole derivatives. The results show that the properties are associated with the different substituents and substitution positions in the parent ring. The symmetric structures and hyperconjugation systems both contribute to the thermal stabilities of the triazole derivatives. It is found that the group $-\mathrm{N}_{3}$ is an effective structural unit for improving the gas phase heat of formation. The calculated detonation properties indicate that $-\mathrm{NO}_{2},-\mathrm{ONO}_{2}$, $-\mathrm{N}_{3},-\mathrm{NF}_{2}$, and $-\mathrm{CH}\left(\mathrm{NO}_{2}\right)_{2}$ groups are very useful for enhancing the detonation velocities and detonation pressures. Thirteen compounds have better detonation properties than that of HMX (1,3,5,7-tetranitro-1,3,5,7tetrazocane). According to the quantitative data of energy and thermal stability for a nitrogen-rich high energetic compound, 20 out of 56 studied compounds may be considered as potential candidates with enhanced performance and reduced sensitivity.
\end{abstract}

Keywords. Density functional theory; triazole; heat of formation; energetics; thermal stability.

\section{Introduction}

To meet the continuing need for improved energy-rich compounds, extensive studies have been focused on nitrogen-rich high energetic compounds with decreased sensitivity and excellent energetic property. ${ }^{1-4}$ Among various types of energy-rich compounds, triazole derivatives constitute a unique class of energetic compound and have received a substantial amount of interest due to their favorable insensitivity, good explosive performance, and environmental acceptability during the past two decades. ${ }^{5-8}$

As a triazole based compound, the most studied nitrotriazole explosive, 3-nitro-1,2,4-triazole-5-one (NTO) was reported by Becuwe and Delclos. ${ }^{9}$ The crystal density of NTO is $>1.90 \mathrm{~g} \cdot \mathrm{cm}^{-3}$, and detonation pressure is equal to that of RDX (1,3,5-trinitro-1,3,5-triazinane). ${ }^{10,11}$ 3-Amino-5-nitro-1,2,4-triazole (ANTA) is a more energetic alternative to NTO. It is reported that ANTA has a density of $1.82 \mathrm{~g} \cdot \mathrm{cm}^{-3}$ and good thermal stability. ${ }^{12}$ 4,6-Bis (5-amino-3-nitro-1,2,4-triazolyl)-5nitropyrimidine (DANTNP) (M.p. $330^{\circ} \mathrm{C}$ ) is another insensitive explosive, which has a density of $1.87 \mathrm{~g} \cdot \mathrm{cm}^{-3}$ and is slightly more powerful while its impact insensitivity is of the order of TATB (1,3,5-triamino-2,4,

*For correspondence 6-trinitrobenzene). ${ }^{13}$ Shreeve et al.,${ }^{14}$ synthesized a series of 1,2,4-triazole-linked energetic polynitropyrazoles, which showed that these compounds have potential applications as energetic compounds. Zhu et al., ${ }^{15}$ designed three novel explosives by introducing the $\mathrm{N}$ oxides into the 1,2,4-triazole, which were more powerful than HMX (1,3,5,7-tetranitro-1,3,5,7-tetrazocane) and less sensitive than TNT (2,4,6-trinitrotoluene). Cheng et al., ${ }^{16}$ reported the synthesis and characterization of the chloride salt of 1,1'-(triaz-1-ene-1,3diyl)bis( $1 H$-tetrazol-5-amine), which contains an $\mathrm{N}_{11}$ structural adduct with 5-aminotetrazole.

Triazole has a nitrogen content of more than $60 \%$ and it is fascinating because of the three hydrogen atoms in the ring which can be replaced with functional groups. ${ }^{17-19}$ It is well-known that the addition of energy-rich substituents, such as $-\mathrm{NO}_{2},-\mathrm{ONO}_{2},-\mathrm{N}_{3}$, $-\mathrm{NF}_{2}$, and $-\mathrm{CH}\left(\mathrm{NO}_{2}\right)_{2}$, create exceptionally powerful explosives, propellants, and fuels with excellent explosive properties. Highly accurate $a b$ initio and density functional theory (DFT) methods predict quantitatively energetic properties, such as density, detonation velocity, detonation pressure, and thermal stability. ${ }^{20,21}$ These methods have been adopted to investigate structure and related properties, and select the most promising nitrogen-rich, high energetic compounds for laboratory synthesis and further consideration. ${ }^{22,23}$ 
In this work, a systematic study was done on the optimized structures, heats of formation in gas phase and in condensed phase, energetic properties, and thermal stabilities of the triazole derivatives by using the DFT method. The main purpose here was to investigate the roles of different substituents and select new triazole-based high energetic compounds. First, 56 triazole derivatives were designed and optimized. Then, the heats of formation in gas phase were calculated via designed isodesmic reactions. The condensed phase heats of formation can be obtained from the gas phase heats of formation and heats of sublimation. In addition, the detonation velocities and pressures were predicted using the calculations of condensed phase heats of formation and theoretical densities. Finally, the thermal stabilities were evaluated based on the bond dissociation energies.

\section{Computational methods}

The molecular frameworks of triazole-based compounds (molecular numbering as A1-A7, B1-B7, C1-C7, D1D7, E1-E7, F1-F7, G1-G7, and H1-H7) are presented in figure 1. Geometry optimization for triazole derivatives were performed at the B3LYP/6-311G(d,p) level of

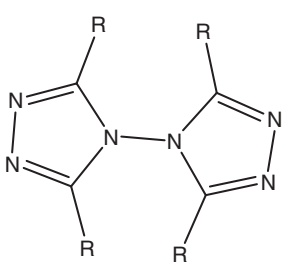

A1 $\mathrm{R}=-\mathrm{H}$

$\mathrm{A} 2 \mathrm{R}=-\mathrm{NH}_{2}$

$\mathrm{A} 3 \mathrm{R}=-\mathrm{NO}_{2}$

$\mathrm{A} 4 \mathrm{R}=-\mathrm{ONO}_{2}$

A5 $\mathrm{R}=-\mathrm{N}_{3}$

A6 $\mathrm{R}=-\mathrm{NF}_{2}$

A7 $\mathrm{R}=-\mathrm{CH}\left(\mathrm{NO}_{2}\right)_{2}$

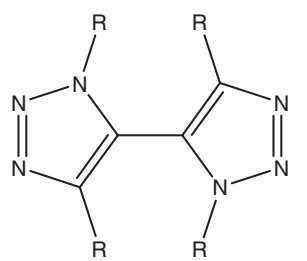

D1 $\mathrm{R}=-\mathrm{H}$

D2 $\mathrm{R}=-\mathrm{NH}_{2}$

D3 $\mathrm{R}=-\mathrm{NO}_{2}$

$\mathrm{D} 4 \mathrm{R}=-\mathrm{ONO}_{2}$

D5 $\mathrm{R}=-\mathrm{N}_{3}$

D6 $\mathrm{R}=-\mathrm{NF}_{2}$

D7 $\mathrm{R}=-\mathrm{CH}\left(\mathrm{NO}_{2}\right)_{2}$

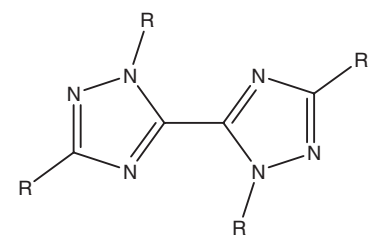

$\mathrm{G} 1 \mathrm{R}=-\mathrm{H}$

$\mathrm{G} 2 \mathrm{R}=-\mathrm{NH}_{2}$

$\mathrm{G} 3 \mathrm{R}=-\mathrm{NO}_{2}$

$\mathrm{G} 4 \mathrm{R}=-\mathrm{ONO}_{2}$

G5 $\mathrm{R}=-\mathrm{N}_{3}$

$\mathrm{G} 6 \mathrm{R}=-\mathrm{NF}_{2}$

$\mathrm{G} 7 \mathrm{R}=-\mathrm{CH}\left(\mathrm{NO}_{2}\right)_{2}$

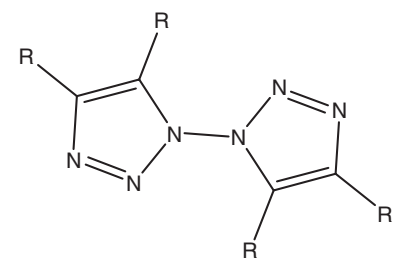

C1 $\mathrm{R}=-\mathrm{H}$

$\mathrm{C} 2 \mathrm{R}=-\mathrm{NH}_{2}$

C3 $\mathrm{R}=-\mathrm{NO}_{2}$

$\mathrm{C} 4 \mathrm{R}=-\mathrm{ONO}_{2}$

C5 $\mathrm{R}=-\mathrm{N}_{3}$

$\mathrm{C} 6 \mathrm{R}=-\mathrm{NF}_{2}$

$\mathrm{C} 7 \mathrm{R}=-\mathrm{CH}\left(\mathrm{NO}_{2}\right)_{2}$<smiles>[R]c1nc([R])n(-n2nc([R])nc2[R])n1</smiles>

$\mathrm{F} 1 \mathrm{R}=-\mathrm{H}$

$\mathrm{F} 2 \mathrm{R}=-\mathrm{NH}_{2}$

$\mathrm{F} 3 \mathrm{R}=-\mathrm{NO}_{2}$

$\mathrm{F} 4 \mathrm{R}=-\mathrm{ONO}_{2}$

$\mathrm{F} 5 \mathrm{R}=-\mathrm{N}_{3}$

$\mathrm{F} 6 \mathrm{R}=-\mathrm{NF}_{2}$

$\mathrm{F} 7 \mathrm{R}=-\mathrm{CH}\left(\mathrm{NO}_{2}\right)_{2}$

Figure 1. Frameworks of triazole-based compounds. 
theory using the Gaussian software package. ${ }^{24}$ The theoretical density was obtained using an improved equation proposed by Politzer et al. ${ }^{25}$ in which the intermolecular interactions were taken into account via the electrostatic interactions on the molecular surface.

$$
\rho=\alpha\left[\frac{M}{V(0.001)}\right]+\beta\left(v \sigma_{t o t}^{2}\right)+\gamma
$$

where, $M$ is molecular mass in $\mathrm{g} \cdot$ molecule $^{-1}$ and $V(0.001)$ is volume in $\mathrm{cm}^{3} \cdot$ molecule ${ }^{-1}$, which is encompassed by the $0.001 \mathrm{e} \cdot \mathrm{Bohr}^{-3}$ contour of the molecule's electronic density; $\alpha, \beta$ and $\gamma$ are the regression coefficients; $v$ is a measure of the degree of balance between positive potential and negative potential on the isosurface, and $\sigma_{\text {tot }}^{2}$ describes the variability of electronic potential on molecular surface.

DFT-B3LYP method ${ }^{26,27}$ with $6-311 \mathrm{G}(\mathrm{d}, \mathrm{p})$ basis set was adopted for prediction of the heat of formation (HOF) in gas phase via designing isodesmic reaction at $298 \mathrm{~K}$. The isodesmic reaction method was employed successfully to calculate gas phase heats of formation $\left(\Delta_{\mathrm{f}} H_{\mathrm{Gas}}^{\mathrm{o}}\right)$ of many organic compounds from the total energies with the help of density functional theory calculations. ${ }^{28,29}$ In the isodesmic reactions, the aza cyclic skeletons of triazole derivatives are kept invariable. The heat of reaction $\left(\Delta H_{298}\right)$ was calculated by the following equation:

$$
\begin{aligned}
\Delta H_{298} & =\sum \Delta H_{\mathrm{f}, \mathrm{P}}-\sum \Delta H_{\mathrm{f}, \mathrm{R}} \\
& =\Delta E_{0}+\Delta \mathrm{ZPE}+\Delta H_{\mathrm{T}}+\Delta n R T
\end{aligned}
$$

where, $\Delta H_{\mathrm{f}, \mathrm{R}}$ and $\Delta H_{\mathrm{f}, \mathrm{P}}$ are the $\Delta_{\mathrm{f}} H_{\mathrm{Gas}}^{\mathrm{o}}$ of reactants and products at $298 \mathrm{~K}$, respectively; $\Delta E_{0}$ and $\Delta \mathrm{ZPE}$ are the differences between the total energies at $0 \mathrm{~K}$ and between the zero-point vibrational energies of products and reactants, respectively; $\Delta H_{\mathrm{T}}$ is thermal correction from $0 \mathrm{~K}$ to $298 \mathrm{~K} ; \Delta n R T$ is work term.

Equation (3) was used to calculate the condensed phase heat of formation $\left(\Delta_{\mathrm{f}} H_{\mathrm{Cond}}^{\mathrm{o}}\right)$ from the $\Delta_{\mathrm{f}} H_{\mathrm{Gas}}^{\mathrm{o}}$ and the heat of sublimation $\left(\Delta H_{\mathrm{Sub}}\right){ }^{30}$

$$
\Delta_{\mathrm{f}} H_{\text {Cond }}^{\mathrm{o}}=\Delta_{\mathrm{f}} H_{\mathrm{Gas}}^{\mathrm{o}}-\Delta H_{\mathrm{Sub}}
$$

Here, $\Delta H_{\text {Sub }}$ is the heat of sublimation estimated using Equation (4) suggested by Rice et al. ${ }^{31}$ and Polizer et al..$^{32}$

$$
\Delta H_{\text {Sub }}=\beta_{1}(S A)^{2}+\beta_{2}\left(\nu \sigma_{\text {tot }}^{2}\right)^{0.5}+\beta_{3}
$$

where, $S A$ is the surface area of $0.001 \mathrm{e} \cdot \mathrm{bohr}^{-3}$ isosurface of electronic density; $v$ is a measure of the degree of balance between positive potential and negative potential on the isosurface; $\sigma_{\text {tot }}^{2}$ describes the variability of electronic potential on molecular surface; $\beta_{1}$, $\beta_{2}$, and $\beta_{3}$ are the correlation coefficients taken from Ref. $^{33}$

Detonation velocity and detonation pressure were calculated by the Kamlet-Jacobs equations ${ }^{34,35}$ as:

$$
\begin{gathered}
P=1.558 N M^{1 / 2} Q^{1 / 2} \rho^{2} \\
D=1.01\left(N M^{1 / 2} Q^{1 / 2}\right)^{1 / 2}(1+1.30 \rho)
\end{gathered}
$$

where, each term in Equations (5) and (6) is defined as follows: $P$, the detonation pressure $(\mathrm{GPa}) ; D$, the detonation velocity $\left(\mathrm{km} \cdot \mathrm{s}^{-1}\right) ; N$, the number moles of detonation gases per gram of explosive; $M$, the average molecular weight of detonation gases; $Q$, the energy of explosion $\left(\mathrm{cal} \cdot \mathrm{g}^{-1}\right) ; \rho$, the crystal density $\left(\mathrm{g} \cdot \mathrm{cm}^{-3}\right)$.

The thermal stability was investigated by evaluating the bond dissociation energy (BDE). ${ }^{36,37}$ In the present study, the BDEs of relatively weak bonds of the triazole derivatives were evaluated using the following equation:

$$
\begin{gathered}
\mathrm{A}-\mathrm{B}(\mathrm{g}) \rightarrow \mathrm{A} \cdot(\mathrm{g})+\mathrm{B} \cdot(\mathrm{g}) \\
\mathrm{BDE}(\mathrm{A}-\mathrm{B})_{\mathrm{ZPE}}=E(\mathrm{~A} \cdot)_{\mathrm{ZPE}}+E(\mathrm{~B} \cdot)_{\mathrm{ZPE}}-E(\mathrm{~A}-\mathrm{B})_{\mathrm{ZPE}}
\end{gathered}
$$

where $\mathrm{A}-\mathrm{B}$ stands for the neutral molecule and $\mathrm{A} \cdot$ and $\mathrm{B}$. for the corresponding product radicals of the dissociation of the $\mathrm{A}-\mathrm{B}$ bond; $\mathrm{BDE}(\mathrm{A}-\mathrm{B})$ is the $\mathrm{BDE}$ of bond $\mathrm{A}-\mathrm{B} ; E(\mathrm{~A}-\mathrm{B})_{\mathrm{ZPE}}, E(\mathrm{~A} \cdot)_{\mathrm{ZPE}}$ and $E(\mathrm{~B} \cdot)_{\mathrm{ZPE}}$ are their corresponding total energies corrected by the zero-point vibrational energies of parent compound and corresponding radicals, respectively.

\section{Results and Discussion}

\subsection{Molecular geometry and electronic structure}

Optimized bond lengths of triazole derivatives are tabulated in table 1. For A1, B1, C1, D1, E1, F1, G1, and $\mathrm{H} 1$, the bond lengths and bond angles of the triazole ring in the ring skeleton are close to those of corresponding compounds. It shows that the substitution of the groups do not affect the bond lengths and bond angles in the triazole ring skeleton significantly. It is proposed that all the $\mathrm{C}-\mathrm{N}$ bonds lengths in ring skeleton of triazole derivatives are between $1.2928 \AA$ and $1.4142 \AA$, which are much shorter than normal C$\mathrm{N}$ single bond that is referred to $1.49 \AA \mathrm{A}^{38}$ All the atoms in the parent structure are in a hyperconjugation system, which can delocalize $\pi$ electron cloud density of system. Consequently, it can be concluded that the hyperconjugation system contributes to the stability of triazole derivatives. 
Table 1. Bond lengths of triazole derivatives computed at B3LYP/6-311G(d,p) level.

\begin{tabular}{|c|c|c|c|c|c|c|c|c|}
\hline Compd. & Bond & Length $(\AA)$ & Bond & Length $(\AA)$ & Bond & Length $(\AA)$ & Bond & Length $(\AA)$ \\
\hline $\mathrm{A} 1$ & $\mathrm{C} 1-\mathrm{N} 3$ & 1.3747 & N3-N8 & 1.3843 & N11-N12 & 1.3790 & N13-N14 & 1.3790 \\
\hline $\mathrm{A} 2$ & $\mathrm{C} 1-\mathrm{N} 3$ & 1.4142 & N3-N6 & 1.4357 & N7-N8 & 1.3737 & $\mathrm{C} 1-\mathrm{N} 20$ & 1.3889 \\
\hline A3 & $\mathrm{C} 1-\mathrm{N} 3$ & 1.3948 & N3-N6 & 1.4107 & N7-N8 & 1.3677 & C1-N14 & 1.4720 \\
\hline A4 & $\mathrm{C} 1-\mathrm{N} 3$ & 1.4101 & N3-N6 & 1.4062 & $\mathrm{C} 1-\mathrm{O} 13$ & 1.3059 & O13-N17 & 1.6670 \\
\hline A5 & $\mathrm{C} 1-\mathrm{N} 3$ & 1.3855 & N3-N6 & 1.3602 & C1-N13 & 1.3813 & N17-N21 & 1.1252 \\
\hline A6 & $\mathrm{C} 1-\mathrm{N} 3$ & 1.3997 & N3-N6 & 1.4146 & C1-N14 & 1.4266 & N14-F21 & 1.3975 \\
\hline A7 & N3-N6 & 1.4210 & N7-N8 & 1.3513 & $\mathrm{C} 1-\mathrm{C} 17$ & 1.4884 & C17-N40 & 1.5352 \\
\hline B1 & $\mathrm{C} 2-\mathrm{N} 3$ & 1.3641 & C2-C6 & 1.4436 & N11-N12 & 1.3769 & N13-N14 & 1.3771 \\
\hline B2 & $\mathrm{C} 2-\mathrm{N} 3$ & 1.3948 & C2-C4 & 1.4672 & N7-N8 & 1.3766 & C1-N14 & 1.3905 \\
\hline B3 & $\mathrm{C} 2-\mathrm{N} 3$ & 1.3789 & C2-C4 & 1.4489 & C1-N14 & 1.4626 & N3-N13 & 1.4619 \\
\hline B4 & $\mathrm{C} 2-\mathrm{C} 4$ & 1.4531 & N7-N8 & 1.3752 & $\mathrm{C} 1-\mathrm{O} 14$ & 1.3149 & O14-N18 & 1.6445 \\
\hline B5 & $\mathrm{C} 2-\mathrm{C} 4$ & 1.4556 & N7-N8 & 1.3797 & $\mathrm{C} 1-\mathrm{N} 14$ & 1.3828 & N3-N13 & 1.4043 \\
\hline B6 & $\mathrm{C} 2-\mathrm{C} 4$ & 1.4666 & $\mathrm{C} 1-\mathrm{N} 12$ & 1.4279 & N3-N11 & 1.3897 & N11-F20 & 1.3939 \\
\hline B7 & $\mathrm{C} 2-\mathrm{C} 4$ & 1.4535 & $\mathrm{C} 1-\mathrm{C} 11$ & 1.4856 & N3-C13 & 1.4267 & C11-N20 & 1.5421 \\
\hline $\mathrm{C} 1$ & $\mathrm{C} 2-\mathrm{N} 3$ & 1.3571 & N6-N7 & 1.3003 & N3-N10 & 1.3736 & N13-N14 & 1.3003 \\
\hline $\mathrm{C} 2$ & $\mathrm{C} 2-\mathrm{C} 3$ & 1.3584 & N3-N8 & 1.3759 & N4-N5 & 1.2970 & C1-N14 & 1.4110 \\
\hline C3 & N3-N8 & 1.3734 & N4-N5 & 1.2874 & C1-N14 & 1.4562 & C2-N13 & 1.4747 \\
\hline $\mathrm{C} 4$ & N3-N8 & 1.3545 & $\mathrm{C} 1-\mathrm{O} 14$ & 1.3343 & $\mathrm{C} 2-\mathrm{O} 13$ & 1.3085 & O14-N18 & 1.5868 \\
\hline C5 & N3-N8 & 1.3545 & N4-N5 & 1.2863 & C1-N14 & 1.3914 & C2-N13 & 1.3772 \\
\hline C6 & N3-N8 & 1.3777 & $\mathrm{C} 1-\mathrm{N} 12$ & 1.4279 & C2-N11 & 1.4234 & N11-F19 & 1.4103 \\
\hline $\mathrm{C} 7$ & N3-N8 & 1.3597 & N4-N5 & 1.2836 & $\mathrm{C} 1-\mathrm{C} 17$ & 1.4913 & C2-C15 & 1.4817 \\
\hline D1 & $\mathrm{C} 2-\mathrm{N} 3$ & 1.3620 & C2-C6 & 1.4434 & N3-N11 & 1.3475 & N11-N12 & 1.2988 \\
\hline D2 & $\mathrm{C} 1-\mathrm{C} 2$ & 1.4086 & C2-C4 & 1.4581 & N3-N7 & 1.3330 & C1-N17 & 1.3784 \\
\hline D3 & C1-N8 & 1.3498 & $\mathrm{C} 2-\mathrm{C} 4$ & 1.4530 & C1-N14 & 1.4592 & N3-N11 & 1.5475 \\
\hline D4 & $\mathrm{C} 2-\mathrm{C} 4$ & 1.4449 & N3-N7 & 1.3570 & $\mathrm{C} 1-\mathrm{O} 14$ & 1.3369 & O14-N18 & 1.5715 \\
\hline D5 & $\mathrm{C} 2-\mathrm{C} 4$ & 1.4393 & C1-N14 & 1.3921 & N3-N11 & 1.3948 & N15-N19 & 1.1248 \\
\hline D6 & $\mathrm{C} 2-\mathrm{C} 4$ & 1.4566 & $\mathrm{C} 1-\mathrm{N} 13$ & 1.4298 & N3-N11 & 1.3955 & N11-F17 & 1.3904 \\
\hline D7 & $\mathrm{C} 2-\mathrm{C} 4$ & 1.4533 & $\mathrm{C} 1-\mathrm{C} 17$ & 1.4850 & N3-C11 & 1.4247 & C11-N19 & 1.5482 \\
\hline E1 & $\mathrm{C} 1-\mathrm{C} 2$ & 1.3781 & C1-N3 & 1.3539 & C2-C6 & 1.4499 & N3-N11 & 1.3480 \\
\hline E2 & $\mathrm{C} 1-\mathrm{C} 2$ & 1.3892 & C2-C4 & 1.4426 & C1-N14 & 1.3651 & N3-N11 & 1.3903 \\
\hline E3 & $\mathrm{C} 2-\mathrm{C} 4$ & 1.4458 & N3-N7 & 1.3484 & C1-N11 & 1.4670 & N3-N12 & 1.4948 \\
\hline E4 & $\mathrm{C} 2-\mathrm{C} 4$ & 1.4387 & $\mathrm{C} 1-\mathrm{O} 12$ & 1.3076 & N3-O11 & 1.3190 & O11-N15 & 1.6429 \\
\hline E5 & $\mathrm{C} 2-\mathrm{C} 4$ & 1.4469 & $\mathrm{C} 1-\mathrm{N} 12$ & 1.3810 & N3-N11 & 1.3907 & N11-N15 & 1.2486 \\
\hline E6 & $\mathrm{C} 2-\mathrm{C} 4$ & 1.4504 & $\mathrm{C} 1-\mathrm{N} 12$ & 1.4170 & N3-N11 & 1.3963 & N11-F15 & 1.3903 \\
\hline E7 & $\mathrm{C} 2-\mathrm{C} 4$ & 1.4489 & $\mathrm{C} 1-\mathrm{C} 15$ & 1.4787 & N3-C17 & 1.4237 & C11-N22 & 1.5473 \\
\hline F1 & C1-N6 & 1.3253 & C2-N7 & 1.3192 & N3-N6 & 1.3469 & N3-N10 & 1.3751 \\
\hline F2 & $\mathrm{C} 2-\mathrm{N} 3$ & 1.3579 & N3-N8 & 1.3821 & $\mathrm{C} 1-\mathrm{N} 20$ & 1.3775 & C2-N11 & 1.3573 \\
\hline F3 & C1-N5 & 1.3490 & N3-N8 & 1.3776 & C1-N13 & 1.4757 & C2-N14 & 1.4769 \\
\hline F4 & N3-N8 & 1.3577 & $\mathrm{C} 1-\mathrm{O} 14$ & 1.3441 & $\mathrm{C} 2-\mathrm{O} 13$ & 1.3159 & O11-N15 & 1.5435 \\
\hline F5 & N3-N8 & 1.3533 & C1-N13 & 1.3897 & C2-N12 & 1.3772 & N11-N15 & 1.2420 \\
\hline F6 & N3-N8 & 1.3818 & $\mathrm{C} 1-\mathrm{N} 14$ & 1.4324 & C2-N11 & 1.4313 & N11-F17 & 1.4116 \\
\hline F7 & N3-N8 & 1.3626 & $\mathrm{C} 1-\mathrm{C} 17$ & 1.4870 & C2-C15 & 1.4858 & C11-N19 & 1.5345 \\
\hline G1 & C1-N6 & 1.3240 & $\mathrm{C} 2-\mathrm{C} 8$ & 1.4457 & N3-N6 & 1.3503 & C8-N14 & 1.3247 \\
\hline G2 & C1-N5 & 1.3586 & C2-C6 & 1.4533 & $\mathrm{C} 1-\mathrm{N} 20$ & 1.3795 & N3-N11 & 1.3916 \\
\hline G3 & $\mathrm{C} 1-\mathrm{N} 4$ & 1.3179 & C2-C6 & 1.4497 & C1-N12 & 1.4736 & N3-N11 & 1.5541 \\
\hline G4 & C2-C6 & 1.4461 & $\mathrm{C} 1-\mathrm{O} 12$ & 1.3423 & N3-O11 & 1.3196 & O11-N15 & 1.6481 \\
\hline G5 & C2-C6 & 1.4476 & $\mathrm{C} 1-\mathrm{N} 14$ & 1.3900 & N3-N11 & 1.3902 & N15-N19 & 1.1290 \\
\hline G6 & C2-C6 & 1.4551 & C1-N14 & 1.4333 & N3-N11 & 1.3896 & N11-F21 & 1.3939 \\
\hline G7 & C2-C6 & 1.4488 & $\mathrm{C} 1-\mathrm{C} 13$ & 1.4852 & N3-C11 & 1.4199 & $\mathrm{C} 11-\mathrm{N} 25$ & 1.5419 \\
\hline H1 & $\mathrm{C} 1-\mathrm{N} 3$ & 1.3522 & C2-N6 & 1.3275 & C2-C9 & 1.4621 & C8-N10 & 1.3522 \\
\hline $\mathrm{H} 2$ & $\mathrm{C} 1-\mathrm{N} 3$ & 1.3628 & $\mathrm{C} 2-\mathrm{C} 7$ & 1.4621 & N3-N4 & 1.3652 & $\mathrm{C} 1-\mathrm{N} 20$ & 1.3831 \\
\hline $\mathrm{H} 3$ & $\mathrm{C} 1-\mathrm{N} 3$ & 1.3677 & $\mathrm{C} 2-\mathrm{C} 7$ & 1.4589 & C1-N12 & 1.4709 & N3-N13 & 1.5006 \\
\hline $\mathrm{H} 4$ & $\mathrm{C} 1-\mathrm{N} 3$ & 1.3835 & $\mathrm{C} 2-\mathrm{C} 7$ & 1.4590 & $\mathrm{C} 1-\mathrm{O} 12$ & 1.3207 & O12-N16 & 1.6204 \\
\hline H5 & $\mathrm{C} 1-\mathrm{N} 3$ & 1.3650 & $\mathrm{C} 2-\mathrm{C} 7$ & 1.4583 & $\mathrm{C} 1-\mathrm{N} 14$ & 1.3818 & N15-N19 & 1.1291 \\
\hline H6 & $\mathrm{C} 1-\mathrm{N} 3$ & 1.3686 & $\mathrm{C} 1-\mathrm{N} 14$ & 1.4302 & N3-N11 & 1.3908 & N11-F15 & 1.3916 \\
\hline H7 & $\mathrm{C} 2-\mathrm{C} 7$ & 1.4598 & $\mathrm{C} 1-\mathrm{C} 13$ & 1.4930 & N3-C11 & 1.4147 & C11-N19 & 1.5448 \\
\hline
\end{tabular}


It can be seen from table 1 that the introduction of the $-\mathrm{NH}_{2},-\mathrm{NO}_{2},-\mathrm{ONO}_{2},-\mathrm{N}_{3},-\mathrm{NF}_{2}$, and $-\mathrm{CH}\left(\mathrm{NO}_{2}\right)_{2}$ groups produce some influences on the geometric parameters of the central ring for each series. For B series, the bond lengths and bond angles in the central ring for the substituted derivatives change slightly compared to the parent compound (B1). For B1, the dihedral angles related to the central ring skeleton such as N8C6-C2-N12, C6-N13-N14-C7, C1-N3-C2-C6 and $\mathrm{N} 3-\mathrm{C} 1-\mathrm{N} 11-\mathrm{N} 12$ equal to $0^{\circ}$ or $180^{\circ}$. The groups attached to central ring skeleton are repulsed, which make them out of plane. The same is true of series A, C, $\mathrm{D}, \mathrm{E}, \mathrm{F}, \mathrm{G}$, and $\mathrm{H}$. In addition, the $\mathrm{C}-\mathrm{NO}_{2}$ bond lengths of all the $-\mathrm{NO}_{2}$ substituted derivatives are in the range of 1.4562-1.4759 $\AA$, which are also shorter than normal $\mathrm{C}-\mathrm{N}$ single bond that is referred to $1.49 \AA,^{38}$ suggesting that the $\mathrm{C}-\mathrm{NO}_{2}$ bonds in triazole derivatives participate in the hyperconjugation system. By analyzing the structures of triazole derivatives, it is easy to find that triazole derivatives are symmetric structures, which make thermal stabilities of triazole derivatives increase. Therefore, it may be inferred that triazole derivatives have good thermal stability and low sensitivity.

Energies (a.u.) of frontier molecular orbitals and their gaps ( $\left.\Delta E_{\mathrm{LUMO}-\mathrm{HOMO}}\right)$ of triazole derivatives at B3LYP/6-311G(d,p) level are listed in table 2. For the triazole derivatives, when the $-\mathrm{NH}_{2}$ and $-\mathrm{N}_{3}$ groups are attached to the ring, the HOMO energies increase, whereas attaching other groups such as $-\mathrm{NO}_{2},-\mathrm{ONO}_{2}$, $-\mathrm{NF}_{2}$, and $-\mathrm{CH}\left(\mathrm{NO}_{2}\right)_{2}$ decrease the HOMO energies. All the title compounds with the substituents $-\mathrm{NO}_{2}$, $\mathrm{ONO}_{2},-\mathrm{N}_{3},-\mathrm{NF}_{2}$, and $-\mathrm{CH}\left(\mathrm{NO}_{2}\right)_{2}$ have lower LUMO energies than the corresponding unsubstituted compounds, whereas those with the $-\mathrm{NH}_{2}$ group have higher LUMO energies. This shows that different substituents exert different effects on the HOMO and LUMO energies of the triazole derivatives. This case is consistent with that of the energy gaps ( $\left.\Delta E_{\mathrm{LUMO}-\mathrm{HOMO}}\right)$. All the substituted derivatives have smaller HOMOLUMO gaps than the corresponding unsubstituted compounds, which reflect a shift toward lower frequencies in their electronic absorption spectra. Among the derivatives, the $\Delta E_{\mathrm{LUMO}-\mathrm{HOMO}}$ of $\mathrm{A} 1$ ( 0.22816 a.u.) is the largest while E4 is the smallest (0.13184 a.u.). Overall, comparing differently substituted compounds leads to a comparison of the energetics.

\subsection{Heats of formation (HOF)}

HOF is usually taken as the indicator of the "energy content' of a energy-rich compound. Therefore, it is very important to predict HOF accurately. Table 3 lists the electronic energies, zero-point energies, thermal
Table 2. Energy of highest occupied molecular orbital $\left(E_{\mathrm{HOMO}}\right)$, energy of lowest unoccupied molecular orbital $\left(E_{\mathrm{LUMO}}\right)$ and energy gaps ( $\left.\Delta E_{\mathrm{LUMO}-\mathrm{HOMO}}\right)$ for the triazole derivatives.

\begin{tabular}{|c|c|c|c|}
\hline Compound & $\begin{array}{l}\text { HOMO } \\
\text { (a.u.) }\end{array}$ & $\begin{array}{l}\text { LUMO } \\
\text { (a.u.) }\end{array}$ & $\begin{array}{c}\Delta E_{\text {LUMO-HOMO }} \\
\text { (a.u.) }\end{array}$ \\
\hline A1 & -0.28572 & -0.05756 & 0.22816 \\
\hline A2 & -0.22590 & -0.01433 & 0.21157 \\
\hline A3 & -0.35142 & -0.18899 & 0.16243 \\
\hline A4 & -0.29339 & -0.14733 & 0.14606 \\
\hline A5 & -0.25753 & -0.07461 & 0.18292 \\
\hline A6 & -0.32264 & -0.14324 & 0.17940 \\
\hline A7 & -0.34532 & -0.17453 & 0.17079 \\
\hline B1 & -0.25709 & -0.04869 & 0.20840 \\
\hline B2 & -0.21112 & -0.02426 & 0.18686 \\
\hline B3 & -0.31957 & -0.18680 & 0.13277 \\
\hline B4 & -0.28815 & -0.13812 & 0.15003 \\
\hline B5 & -0.25294 & -0.11619 & 0.13675 \\
\hline B6 & -0.31302 & -0.13718 & 0.17584 \\
\hline B7 & -0.33096 & -0.16028 & 0.17068 \\
\hline $\mathrm{C} 1$ & -0.28329 & -0.06648 & 0.21681 \\
\hline $\mathrm{C} 2$ & -0.21706 & -0.02608 & 0.19098 \\
\hline $\mathrm{C} 3$ & -0.35269 & -0.15363 & 0.19906 \\
\hline $\mathrm{C} 4$ & -0.29882 & -0.14110 & 0.15772 \\
\hline $\mathrm{C} 5$ & -0.24953 & -0.09594 & 0.15359 \\
\hline C6 & -0.32537 & -0.13850 & 0.18687 \\
\hline $\mathrm{C} 7$ & -0.33847 & -0.16184 & 0.17663 \\
\hline D1 & -0.26201 & -0.06612 & 0.19589 \\
\hline D2 & -0.19210 & -0.04284 & 0.14926 \\
\hline D3 & -0.32394 & -0.17752 & 0.14642 \\
\hline D4 & -0.28857 & -0.14592 & 0.14265 \\
\hline D5 & -0.24898 & -0.09734 & 0.15164 \\
\hline D6 & -0.31286 & -0.14983 & 0.16303 \\
\hline D7 & -0.34326 & -0.15512 & 0.18814 \\
\hline E1 & -0.23997 & -0.02016 & 0.21981 \\
\hline $\mathrm{E} 2$ & -0.18427 & 0.00251 & 0.18678 \\
\hline E3 & -0.30808 & -0.15135 & 0.15673 \\
\hline $\mathrm{E} 4$ & -0.26760 & -0.13576 & 0.13184 \\
\hline E5 & -0.23786 & -0.09813 & 0.13973 \\
\hline E6 & -0.31641 & -0.12751 & 0.18890 \\
\hline E7 & -0.31643 & -0.14775 & 0.16868 \\
\hline $\mathrm{F} 1$ & -0.27712 & -0.05594 & 0.22118 \\
\hline $\mathrm{F} 2$ & -0.19085 & 0.01096 & 0.20181 \\
\hline F3 & -0.34457 & -0.15271 & 0.19186 \\
\hline F4 & -0.30923 & -0.13175 & 0.17748 \\
\hline F5 & -0.26797 & -0.09188 & 0.17609 \\
\hline F6 & -0.32913 & -0.13016 & 0.19897 \\
\hline F7 & -0.34715 & -0.15013 & 0.19702 \\
\hline G1 & -0.26343 & -0.05986 & 0.20357 \\
\hline $\mathrm{G} 2$ & -0.21011 & -0.03258 & 0.17753 \\
\hline G3 & -0.33076 & -0.15331 & 0.17745 \\
\hline G4 & -0.29518 & -0.13338 & 0.16180 \\
\hline G5 & -0.25210 & -0.09452 & 0.15758 \\
\hline G6 & -0.31929 & -0.13401 & 0.18528 \\
\hline G7 & -0.33158 & -0.15159 & 0.17999 \\
\hline H1 & -0.24655 & -0.01954 & 0.22701 \\
\hline $\mathrm{H} 2$ & -0.20786 & -0.00340 & 0.20446 \\
\hline H3 & -0.31916 & -0.15064 & 0.16852 \\
\hline $\mathrm{H} 4$ & -0.27550 & -0.12315 & 0.15235 \\
\hline H5 & -0.24049 & -0.09157 & 0.14892 \\
\hline H6 & -0.32202 & -0.11565 & 0.20637 \\
\hline $\mathrm{H} 7$ & -0.31829 & -0.14580 & 0.17249 \\
\hline
\end{tabular}


Table 3. Calculated electronic energies $\left(E_{0}\right)$, zero-point energies (ZPE), thermal corrections to enthalpy $\left(H_{\mathrm{T}}\right)$ and gas phase heats of formation of the reference compounds. ${ }^{\mathrm{a}}$

\begin{tabular}{lcccc}
\hline Compound & $E_{0}$ (a.u.) & ZPE (a.u.) & $H_{\mathrm{T}}\left(\mathrm{kJ} \cdot \mathrm{mol}^{-1}\right)$ & $\mathrm{HOF}\left(\mathrm{kJ} \cdot \mathrm{mol}^{-1}\right)$ \\
\hline $\mathrm{CH}_{4}$ & -40.4891 & 0.0437 & 9.61 & $-74.60^{\mathrm{b}}$ \\
$\mathrm{CH}_{3} \mathrm{CH}_{3}$ & -79.7819 & 0.0729 & 11.16 & $-84.00^{\mathrm{b}}$ \\
$\mathrm{CH}_{3} \mathrm{NH}_{2}$ & -95.8246 & 0.0625 & 10.96 & $-22.50^{\mathrm{b}}$ \\
$\mathrm{CH}_{3} \mathrm{NO}_{2}$ & -245.0319 & 0.0488 & 13.17 & $-80.80^{\mathrm{b}}$ \\
$\mathrm{CH}_{3} \mathrm{ONO}_{2}$ & -320.2174 & 0.0524 & 13.53 & $-124.40^{\mathrm{b}}$ \\
$\mathrm{CH}_{3} \mathrm{~N}_{3}$ & -204.0982 & 0.0492 & 13.65 & $296.50^{\mathrm{c}}$ \\
$\mathrm{CH}_{3} \mathrm{NF}_{2}$ & -294.2516 & 0.0459 & 13.06 & $-114.78^{\mathrm{c}}$ \\
$4 H-1,2,4$-triazole & -242.2438 & 0.0577 & 11.50 & $217.93^{\mathrm{d}}$ \\
$1 H-1,2,3$-triazole & -242.2270 & 0.0577 & 11.43 & $267.03^{\mathrm{d}}$ \\
$1 \mathrm{H}-1,2,4$-triazole & -242.2537 & 0.0585 & 11.32 & $193.45^{\mathrm{d}}$ \\
\hline
\end{tabular}

${ }^{a}$ The scaling factor is 0.98 for the ZPE and 0.96 for $H_{\mathrm{T}}{ }^{39}$

b The experimental HOFs were taken from Ref, ${ }^{40-42}$ respectively.

${ }^{c}$ The theoretical HOFs were taken from Ref. ${ }^{43}$

d The theoretical HOFs were taken from Ref. ${ }^{44}$

corrections, and gas phase heats of formation for the reference compounds in the isodesmic reactions. Figure 2 displays the comparison of the HOFs of triazole derivatives with different substituents. The isodesmic reaction was used to derive the gas phase heat of formation $\Delta_{\mathrm{f}} H_{\mathrm{Gas}}^{\mathrm{o}}$ of triazole derivatives at $298 \mathrm{~K}$ (scheme 1).

Table 4 presents the total energies, ZPEs, thermal corrections, molecular properties, and gas phase and condensed phase heats of formation of the triazole derivatives. The effects of different substituents on the gas phase and condensed phase heats of formation of the triazole derivatives were investigated. For the A series, when the substituents are $-\mathrm{NH}_{2},-\mathrm{NO}_{2},-\mathrm{N}_{3}$, $-\mathrm{NF}_{2}$, and $-\mathrm{CH}\left(\mathrm{NO}_{2}\right)_{2}$, the $\Delta_{\mathrm{f}} H_{\text {Gas }}^{\mathrm{o}}$ of $\mathrm{A} 2, \mathrm{~A} 3, \mathrm{~A} 5$, A6, A7 increase compared with the unsubstituted case (A1), whereas the opposite is true for the substituent $-\mathrm{ONO}_{2}$. This also holds for the B, D, E, G, and $\mathrm{H}$ series. However, for the $\mathrm{C}$ and $\mathrm{F}$ series, the situation is different. The substitution of $-\mathrm{NO}_{2},-\mathrm{N}_{3}$ or $-\mathrm{NF}_{2}$ increases the $\Delta_{\mathrm{f}} H_{\mathrm{Gas}}^{\mathrm{o}}$ values of $\mathrm{C} 3, \mathrm{C} 5, \mathrm{C} 6, \mathrm{~F} 3, \mathrm{~F} 5$

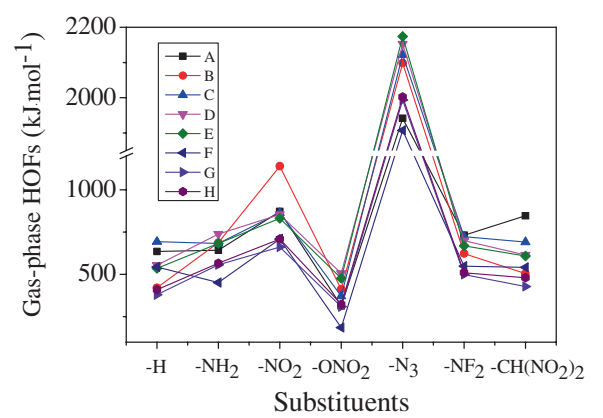

and F6, respectively, while the substitution of $-\mathrm{NH}_{2}$, $-\mathrm{ONO}_{2}$ or $-\mathrm{CH}\left(\mathrm{NO}_{2}\right)_{2}$ has the opposite effect. $-\mathrm{N}_{3}$ substituted derivatives have the largest $\Delta_{\mathrm{f}} H_{\mathrm{Gas}}^{\mathrm{o}}$ values $\left(\Delta_{\mathrm{f}} H_{\text {Gas }}^{\mathrm{o}}>1900 \mathrm{~kJ} \cdot \mathrm{mol}^{-1}\right)$ than the other substituted ones in the series. In addition, substitution of the group $-\mathrm{ONO}_{2}$ greatly decreases the $\Delta_{\mathrm{f}} H_{\text {Gas }}^{\mathrm{o}}$ values compared with those of the unsubstituted compounds. This shows that the substitution of $-\mathrm{N}_{3}$ is helpful for increasing the gas phase heats of formation of the triazole derivatives, while substituting $-\mathrm{ONO}_{2}$ greatly reduces $\Delta_{\mathrm{f}} H_{\text {Gas }}^{\mathrm{o}}$ values.

From figure 2, it was found that, qualitatively, the calculated condensed phase heats of formation $\left(\Delta_{\mathrm{f}} H_{\text {Cond }}^{\mathrm{o}}\right)$ show the same trend as the gas phase heats of formation $\left(\Delta_{\mathrm{f}} H_{\mathrm{Gas}}^{\mathrm{o}}\right)$. This shows that the trend in the heats of formation of the triazole derivatives observed when the substituents are varied, is similar for the compounds in the gas phase and for those in the condensed phase. As shown in table 4, among the 56 triazole derivatives, 28 molecules possess a $\Delta_{\mathrm{f}} H_{\text {Cond }}^{\mathrm{o}}$ values $>500 \mathrm{~kJ} \cdot \mathrm{mol}^{-1}$.

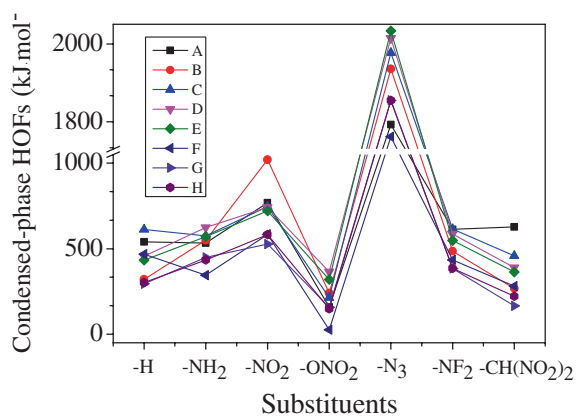

Figure 2. Comparison of the HOFs of triazole derivatives with different substituents. 
供

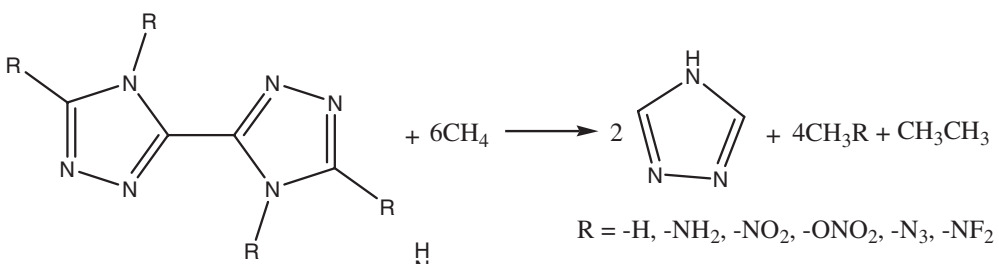<smiles>CCO[N+](C)=O</smiles>

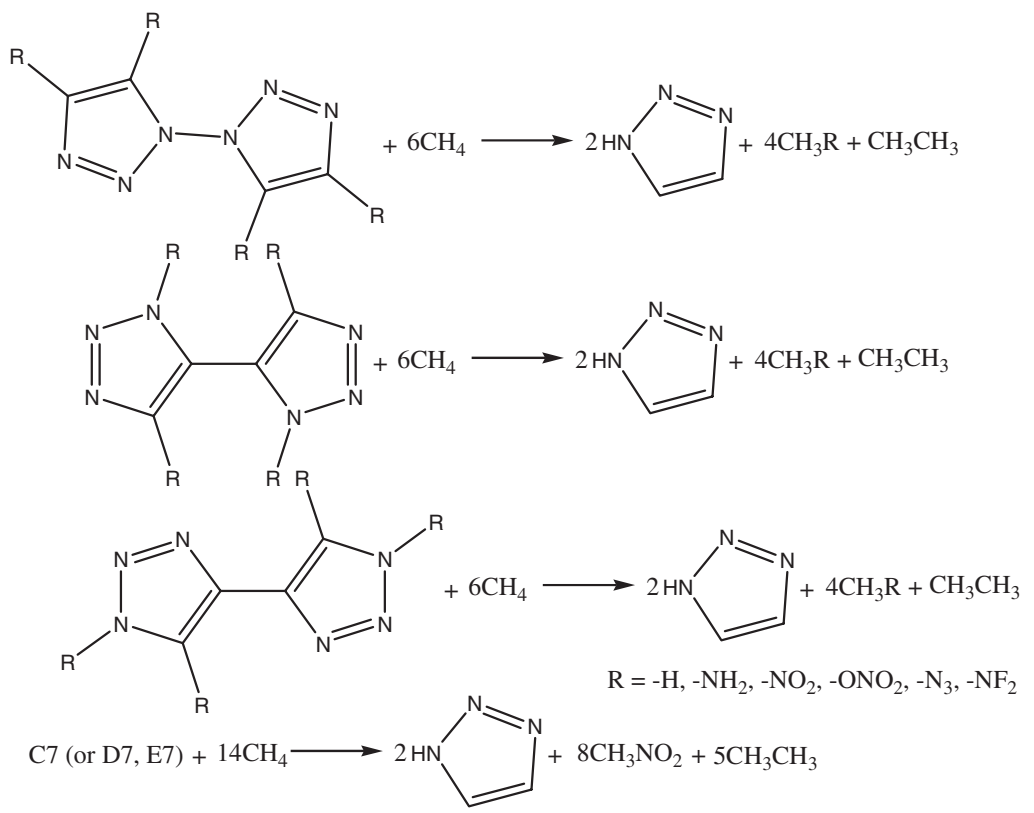

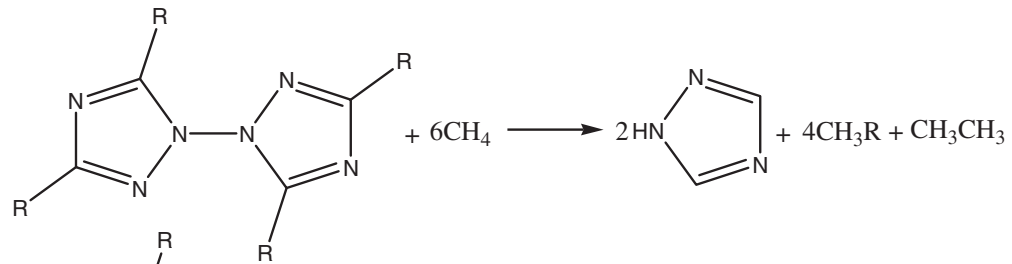

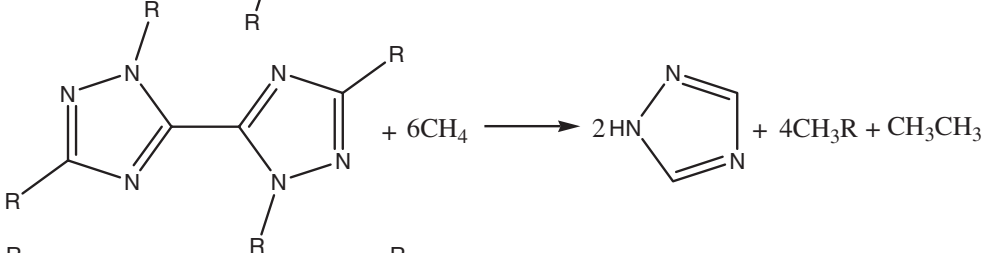

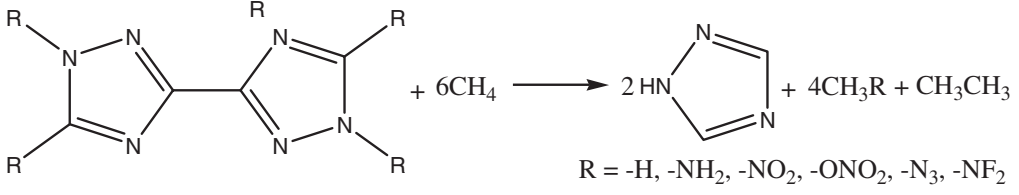<smiles>CO[N+](C)=O</smiles>

Scheme 1. The isodesmic reactions of triazole derivatives. 
Table 4. Calculated total energies ( $E_{0}$, a.u.), zero-point energies (ZPE, a.u.), thermal corrections $\left(H_{\mathrm{T}}, \mathrm{kJ} \cdot \mathrm{mol}^{-1}\right)$, molecular properties, heats of sublimation $\left(\mathrm{kJ} \cdot \mathrm{mol}^{-1}\right)$, and heats of formation $\left(\mathrm{kJ} \cdot \mathrm{mol}^{-1}\right)$ for the triazole derivatives. ${ }^{\text {a }}$

\begin{tabular}{|c|c|c|c|c|c|c|c|c|c|}
\hline Compd & $E_{0}$ & $\mathrm{ZPE}$ & $H_{\mathrm{T}}$ & $\Delta_{\mathrm{f}} H_{\mathrm{Gas}}^{\mathrm{o}}$ & $S A$ & $v$ & $\sigma_{\text {tot }}^{2}$ & $\Delta H_{\text {Sub }}$ & $\Delta_{\mathrm{f}} H_{\text {Cond }}^{\mathrm{o}}$ \\
\hline A1 & -483.2415 & 0.0950 & 18.3936 & 635.39 & 157.40 & 0.24 & 264.19 & 95.47 & 539.92 \\
\hline A2 & -704.6623 & 0.1636 & 30.5280 & 643.56 & 200.13 & 0.23 & 270.22 & 111.45 & 532.11 \\
\hline A3 & -1301.3172 & 0.1030 & 43.1040 & 871.75 & 244.02 & 0.06 & 214.40 & 103.13 & 768.62 \\
\hline A4 & -1602.2100 & 0.1156 & 57.3984 & 314.30 & 293.95 & 0.25 & 179.32 & 155.02 & 159.28 \\
\hline A5 & -1137.7511 & 0.1075 & 48.1536 & 1941.77 & 294.61 & 0.22 & 152.12 & 149.23 & 1792.54 \\
\hline A6 & -1498.1996 & 0.0899 & 47.3088 & 730.85 & 247.25 & 0.10 & 294.22 & 118.47 & 612.38 \\
\hline A7 & -2276.6531 & 0.2225 & 84.3744 & 847.05 & 408.11 & 0.04 & 275.66 & 220.36 & 626.69 \\
\hline B1 & -483.3237 & 0.0970 & 20.3232 & 421.49 & 157.99 & 0.25 & 307.96 & 100.58 & 320.91 \\
\hline B2 & -704.6459 & 0.1614 & 31.6608 & 687.78 & 211.65 & 0.22 & 552.39 & 138.76 & 549.02 \\
\hline B3 & -1301.2161 & 0.0992 & 44.9952 & 1139.11 & 250.33 & 0.11 & 270.91 & 119.57 & 1019.54 \\
\hline B4 & -1602.1736 & 0.1162 & 59.7504 & 412.45 & 306.80 & 0.25 & 248.74 & 172.09 & 240.36 \\
\hline B5 & -1137.6918 & 0.1052 & 48.8544 & 2098.32 & 289.00 & 0.25 & 275.81 & 162.70 & 1935.62 \\
\hline B6 & -1498.2412 & 0.0895 & 48.6624 & 622.99 & 256.26 & 0.21 & 271.24 & 137.84 & 485.15 \\
\hline B7 & -2276.7842 & 0.2245 & 86.7744 & 505.41 & 419.62 & 0.07 & 229.44 & 237.63 & 267.78 \\
\hline $\mathrm{C} 1$ & -483.2232 & 0.0949 & 18.0960 & 693.09 & 158.34 & 0.24 & 142.50 & 80.92 & 612.17 \\
\hline $\mathrm{C} 2$ & -704.6522 & 0.1605 & 33.3600 & 683.17 & 210.24 & 0.25 & 180.68 & 108.20 & 574.97 \\
\hline C3 & -1301.3250 & 0.1023 & 45.6000 & 864.07 & 262.79 & 0.07 & 259.62 & 118.93 & 745.14 \\
\hline C4 & -1602.1932 & 0.1158 & 60.2688 & 371.71 & 313.89 & 0.19 & 141.47 & 158.71 & 213.00 \\
\hline C5 & -1137.6866 & 0.1056 & 48.8640 & 2121.92 & 282.68 & 0.23 & 171.01 & 145.26 & 1976.66 \\
\hline C6 & -1498.2066 & 0.0893 & 48.6336 & 724.04 & 256.31 & 0.08 & 170.50 & 110.63 & 613.41 \\
\hline C7 & -2276.7173 & 0.2237 & 86.8800 & 691.35 & 411.67 & 0.07 & 280.71 & 232.99 & 458.36 \\
\hline D1 & -483.2759 & 0.0962 & 18.5280 & 555.41 & 158.27 & 0.20 & 361.97 & 99.30 & 456.11 \\
\hline D2 & -704.6304 & 0.1631 & 31.7088 & 738.81 & 203.33 & 0.25 & 264.69 & 114.77 & 624.04 \\
\hline D3 & -1301.3288 & 0.1022 & 46.3872 & 854.74 & 246.66 & 0.15 & 154.53 & 113.19 & 741.55 \\
\hline D4 & -1602.1406 & 0.1160 & 56.7264 & 506.13 & 293.07 & 0.21 & 110.44 & 141.35 & 364.78 \\
\hline D5 & -1137.6747 & 0.1055 & 48.4704 & 2152.77 & 285.57 & 0.25 & 101.49 & 138.35 & 2014.42 \\
\hline D6 & -1498.2155 & 0.0897 & 47.4528 & 699.43 & 250.18 & 0.11 & 202.75 & 114.32 & 585.11 \\
\hline D7 & -2276.7465 & 0.2236 & 87.0912 & 614.86 & 409.18 & 0.05 & 284.28 & 224.94 & 389.92 \\
\hline E1 & -483.2841 & 0.0968 & 20.3232 & 535.75 & 158.14 & 0.23 & 355.45 & 102.68 & 433.07 \\
\hline E2 & -704.6525 & 0.1626 & 34.6176 & 683.76 & 211.29 & 0.25 & 221.94 & 113.73 & 570.03 \\
\hline E3 & -1301.3376 & 0.1018 & 46.1664 & 831.53 & 264.40 & 0.12 & 162.26 & 110.48 & 721.05 \\
\hline E4 & -1602.1531 & 0.1159 & 60.0384 & 476.74 & 311.24 & 0.20 & 136.05 & 156.36 & 320.38 \\
\hline E5 & -1137.6668 & 0.1052 & 49.5168 & 2174.52 & 285.74 & 0.25 & 118.76 & 141.15 & 2033.37 \\
\hline E6 & -1498.2273 & 0.0895 & 48.1920 & 669.29 & 260.12 & 0.18 & 126.07 & 121.34 & 547.95 \\
\hline E7 & -2276.7488 & 0.2241 & 86.9280 & 608.46 & 425.47 & 0.06 & 338.90 & 244.64 & 363.82 \\
\hline F1 & -483.2773 & 0.0965 & 17.8656 & 544.56 & 157.71 & 0.23 & 121.20 & 76.53 & 468.03 \\
\hline F2 & -704.7377 & 0.1624 & 32.7072 & 451.59 & 210.75 & 0.24 & 172.92 & 106.69 & 344.90 \\
\hline F3 & -1301.3817 & 0.1037 & 45.8304 & 709.12 & 270.63 & 0.09 & 224.41 & 125.68 & 583.44 \\
\hline F4 & -1602.2612 & 0.1181 & 59.2224 & 185.69 & 324.51 & 0.16 & 116.68 & 159.62 & 26.07 \\
\hline F5 & -1137.7653 & 0.1077 & 47.6256 & 1907.71 & 287.58 & 0.23 & 155.13 & 146.08 & 1761.63 \\
\hline F6 & -1498.2710 & 0.0911 & 48.1248 & 548.23 & 260.81 & 0.07 & 190.82 & 113.39 & 434.84 \\
\hline F7 & -2276.7722 & 0.2240 & 88.3008 & 542.11 & 445.78 & 0.06 & 253.31 & 260.79 & 281.32 \\
\hline G1 & -483.3410 & 0.0984 & 20.0352 & 379.62 & 157.72 & 0.21 & 194.58 & 84.70 & 294.92 \\
\hline G2 & -704.6985 & 0.1631 & 36.0288 & 557.48 & 216.78 & 0.25 & 166.66 & 109.52 & 447.96 \\
\hline G3 & -1301.4008 & 0.1030 & 48.3936 & 661.60 & 269.77 & 0.17 & 201.77 & 134.33 & 527.27 \\
\hline G4 & -1602.2139 & 0.1181 & 58.6368 & 309.31 & 318.16 & 0.16 & 84.02 & 151.03 & 158.28 \\
\hline G5 & -1137.7330 & 0.1068 & 48.0864 & 1993.09 & 291.65 & 0.25 & 81.15 & 138.33 & 1854.76 \\
\hline G6 & -1498.2905 & 0.0913 & 50.1504 & 498.93 & 264.75 & 0.08 & 160.97 & 115.02 & 383.91 \\
\hline G7 & -2276.8150 & 0.2251 & 87.2544 & 428.90 & 441.94 & 0.09 & 248.78 & 263.23 & 165.67 \\
\hline H1 & -483.3293 & 0.0978 & 20.2368 & 410.53 & 158.30 & 0.25 & 383.57 & 107.96 & 302.57 \\
\hline H2 & -704.6951 & 0.1632 & 34.7904 & 565.59 & 218.82 & 0.23 & 378.85 & 130.84 & 434.75 \\
\hline H3 & -1301.3974 & 0.1033 & 47.8560 & 709.12 & 271.65 & 0.14 & 153.68 & 126.62 & 582.50 \\
\hline $\mathrm{H} 4$ & -1602.2090 & 0.1174 & 59.4144 & 322.94 & 321.73 & 0.23 & 184.84 & 173.55 & 149.39 \\
\hline H5 & -1137.7299 & 0.1064 & 49.1136 & 2002.18 & 294.68 & 0.23 & 128.47 & 147.17 & 1855.01 \\
\hline H6 & -1498.2861 & 0.0910 & 50.3328 & 510.82 & 267.37 & 0.17 & 135.73 & 125.98 & 384.84 \\
\hline H7 & -2276.7950 & 0.2246 & 87.1008 & 481.18 & 439.74 & 0.06 & 324.80 & 259.24 & 221.94 \\
\hline
\end{tabular}

a The scaling factor is 0.98 for ZPE and 0.96 for $H_{\mathrm{T}} \cdot{ }^{39} U(S A)=0.01 \AA^{2}, U\left(\sigma_{\text {tot }}^{2}\right)=0.01 \mathrm{~kJ}^{2} \cdot \mathrm{mol}^{-2}$. 
E5 has the highest $\Delta_{\mathrm{f}} H_{\text {Cond }}^{\mathrm{o}}$ value $\left(2033.37 \mathrm{~kJ} \cdot \mathrm{mol}^{-1}\right)$ among all the 56 triazole derivatives. Obviously, different substituents exert diverse influences on condensed phase heats of formation. $-\mathrm{NO}_{2},-\mathrm{N}_{3}$, and $-\mathrm{NF}_{2}$ groups increase $\Delta_{\mathrm{f}} H_{\text {Cond }}^{\mathrm{o}}$ values, and their contribution to the $\Delta_{\mathrm{f}} H_{\text {Cond }}^{\mathrm{o}}$ value is in the order of $-\mathrm{N}_{3}>-\mathrm{NO}_{2}>$ $-\mathrm{NF}_{2}$. Whereas $-\mathrm{ONO}_{2}$, and $-\mathrm{CH}\left(\mathrm{NO}_{2}\right)_{2}$ groups lead to a small decrease in $\Delta_{\mathrm{f}} H_{\text {Cond }}^{\mathrm{o}}$ values. $-\mathrm{N}_{3}$ derivative is much larger than that of other derivatives, which is in agreement with previous observations that the azido group is one of the most energetic functional groups currently known. ${ }^{45,46}$

\subsection{Energetic properties}

Detonation velocity $(D)$ and detonation pressure $(P)$ are two important parameters for triazole-based high energetic compounds. Table 5 presents the predicted densities, heats of detonation, detonation velocities, detonation pressures, and oxygen balances for these compounds. For comparisons, the experimental detonation performance of known explosive RDX and HMX are also tabulated in table 5. As shown in table 5, all the substituted derivatives have relatively high $\rho$ values. The introduction of the substituted groups greatly increases the $\rho$ values of the unsubstituted compounds. The $-\mathrm{NF}_{2}$ substituted triazole derivatives have the largest $\rho$ values in the same series. B6 has the highest $\rho$ value $\left(2.20 \mathrm{~g} \cdot \mathrm{cm}^{-3}\right)$ among all the 56 compounds.

The calculated heats of detonation in table 5 show that substituting $-\mathrm{NO}_{2},-\mathrm{ONO}_{2},-\mathrm{N}_{3},-\mathrm{NF}_{2}$, and $-\mathrm{CH}\left(\mathrm{NO}_{2}\right)_{2}$ increase the heats of detonation compared to that of the corresponding unsubstituted compounds, whereas the opposite is true for $-\mathrm{NH}_{2}$, indicating that the $-\mathrm{NO}_{2},-\mathrm{ONO}_{2},-\mathrm{N}_{3},-\mathrm{NF}_{2}$, and $-\mathrm{CH}\left(\mathrm{NO}_{2}\right)_{2}$ groups are helpful for increasing their heats of explosion, while the substitution of $-\mathrm{NH}_{2}$ reduces their $Q$ values. There are 19 compounds with higher $Q$ than RDX. B3 has the highest $Q$ value $\left(1961.61 \mathrm{~J} \cdot \mathrm{g}^{-1}\right)$ among all the compounds.

The effects of the substituents on the densities mean that the triazole derivatives have different detonation velocities, and detonation pressures. $-\mathrm{NF}_{2}$ or $-\mathrm{NO}_{2}$ substituted derivatives have higher detonation velocities, and detonation pressures than the other substituted ones, and the derivatives with the $-\mathrm{NF}_{2}$ group have the largest $D$ and $P$ values $\left(D>9.80 \mathrm{~km} \cdot \mathrm{s}^{-1}\right.$ and $P>$ $46.00 \mathrm{GPa})$. This shows that the substitutions of $-\mathrm{NO}_{2}$ and especially $-\mathrm{NF}_{2}$ are helpful for increasing the detonation properties of the triazole derivatives. Because of the low densities, the $-\mathrm{N}_{3}$ substituted derivatives have the largest $\Delta_{\mathrm{f}} H_{\text {Cond }}^{\mathrm{o}}$ among triazole derivatives, but their explosive performance is not outstanding. In addition, B6 has the highest $D\left(10.49 \mathrm{~km} \cdot \mathrm{s}^{-1}\right)$ and $P(54.56 \mathrm{GPa})$ values among the 56 designed compounds.

Besides, the relative positions of triazoles influence not only $\Delta_{\mathrm{f}} H_{\text {Gas }}^{\mathrm{o}}$ but also the energetic properties. For instance, C3 has slightly higher density, heat of detonation, detonation velocity, and detonation pressure than E3, whereas the isomer D3 with one more $\mathrm{N}-\mathrm{N}$ bond has the largest corresponding values, same as that of other isomers. Based on the above analyses, it can be concluded that $-\mathrm{NO}_{2},-\mathrm{ONO}_{2},-\mathrm{N}_{3},-\mathrm{NF}_{2}$, and $-\mathrm{CH}\left(\mathrm{NO}_{2}\right)_{2}$ groups are effective structural units for increasing the densities and detonation properties of triazole derivatives, especially $-\mathrm{NO}_{2}$, and $-\mathrm{NF}_{2}$ structural units. In addition, the oxygen balance is another important criterion for selecting potential high energetic compounds. $-\mathrm{NO}_{2}$ group is good for improving the oxygen balance. It is seen in table 5 that A3, B3, C3, D3, E3, F3, G3, and H3 have perfect oxygen balance equal to zero, that is, it does not need any atmospheric oxygen to combust and it gives off more energy during the explosion. Therefore, in the design of molecules, one shall better keep the oxygen balance equal to zero.

Figure 3 displays the comparison of the calculated $\rho$, $Q, D$ and $P$ values of triazole derivatives with different substituents. It is clear that the trend in $\rho$ throughout the series is very similar to the trends seen for $D$ and $P$ in the triazole derivatives. However, some of the triazole derivatives have higher $\rho$ values but lower $D$ and $P$ values than nitramine RDX or HMX. This is because their heats of detonation cause the densities to have less influence on $D$ and $P$. This in turn shows that the density is not always the key factor when determining detonation properties.

Considering the quantitative criteria of high energetic compounds, that is, $\rho \approx 1.90 \mathrm{~g} \cdot \mathrm{cm}^{-3}, D \approx 9.0 \mathrm{~km} \cdot \mathrm{s}^{-1}$, and $P \approx 40.0 \mathrm{GPa}$, it is found from table 5 that series $\mathrm{A}$ (A3, A6), series B (B3, B6), series C (C3, C6), series D (D3, D6, D7), series E (E3, E6), series F (F3, F6), series G (G3, G6), and series H (H3, H6) satisfy the requirements. Moreover, most derivatives of A-H (A3, A6, B3, B6, C6, D3, D6, D7, E6, F6, G3, G6, H6) have better detonation properties over the famous nitramine explosive HMX $\left(\rho=1.91 \mathrm{~g} \cdot \mathrm{cm}^{-3}, D=9.10 \mathrm{~km} \cdot \mathrm{s}^{-1}, P=\right.$ $39.00 \mathrm{GPa})$. If compared with another commonly used explosive RDX $\left(\rho=1.82 \mathrm{~g} \cdot \mathrm{cm}^{-3}, D=8.75 \mathrm{~km} \cdot \mathrm{s}^{-1}\right.$, $P=34.00 \mathrm{GPa})$, the triazole derivatives have much better explosive performance. Therefore, if A3, A6, B3, B6, C3, C6, D3, D6, D7, E3, E6, F3, F6, G3, G6, H3, and $\mathrm{H} 6$ can be synthesized, these derivatives will have better exploitable values. Thus, further investigations are still needed. 
Table 5. Predicted densities $\left(\rho, \mathrm{g} \cdot \mathrm{cm}^{-3}\right)$, heats of detonation $\left(Q, \mathrm{~J} \cdot \mathrm{g}^{-1}\right)$, detonation velocities $\left(D, \mathrm{~km} \cdot \mathrm{s}^{-1}\right)$, detonation pressures $(P, \mathrm{GPa})$, and oxygen balance $(O B, \%)$ for the triazole derivatives.

\begin{tabular}{|c|c|c|c|c|c|}
\hline Compd. & $O B$ & $\rho$ & $Q$ & $D$ & $P$ \\
\hline A1 & -117.65 & 1.58 & 948.83 & 6.72 & 18.48 \\
\hline A2 & -97.96 & 1.61 & 648.85 & 6.80 & 19.16 \\
\hline A3 & 0 & 1.91 & 1771.84 & 9.38 & 40.38 \\
\hline A4 & 16.84 & 2.02 & 1090.18 & 8.68 & 35.71 \\
\hline A5 & -42.67 & 1.73 & 1428.06 & 8.04 & 27.97 \\
\hline A6 & & 2.15 & 1830.47 & 10.44 & 53.43 \\
\hline A7 & -5.80 & 1.85 & 1673.42 & 9.03 & 36.73 \\
\hline B1 & -117.65 & 1.65 & 563.95 & 6.08 & 15.54 \\
\hline B2 & -97.96 & 1.79 & 669.47 & 7.38 & 24.05 \\
\hline B3 & 0 & 1.94 & 1961.61 & 9.73 & 43.83 \\
\hline B4 & 16.84 & 2.01 & 1141.17 & 8.75 & 36.18 \\
\hline B5 & -42.67 & 1.80 & 1542.04 & 8.42 & 31.47 \\
\hline B6 & & 2.20 & 1741.03 & 10.49 & 54.56 \\
\hline B7 & -5.80 & 1.86 & 1518.02 & 8.84 & 35.36 \\
\hline $\mathrm{C} 1$ & -117.65 & 1.50 & 1075.80 & 6.70 & 17.73 \\
\hline $\mathrm{C} 2$ & -97.96 & 1.58 & 701.11 & 6.85 & 19.18 \\
\hline $\mathrm{C} 3$ & 0 & 1.86 & 1754.08 & 9.18 & 38.10 \\
\hline $\mathrm{C} 4$ & 16.84 & 1.88 & 1123.97 & 8.31 & 31.41 \\
\hline C5 & -42.67 & 1.73 & 1574.74 & 8.24 & 29.37 \\
\hline C6 & & 2.07 & 1831.19 & 10.15 & 49.54 \\
\hline $\mathrm{C} 7$ & -5.80 & 1.88 & 1600.54 & 9.03 & 37.10 \\
\hline D1 & -117.65 & 1.62 & 801.55 & 6.56 & 17.85 \\
\hline D2 & -97.96 & 1.63 & 760.95 & 7.14 & 21.16 \\
\hline D3 & 0 & 1.89 & 1751.36 & 9.28 & 39.31 \\
\hline D4 & 16.84 & 1.92 & 1219.43 & 8.61 & 34.12 \\
\hline D5 & -42.67 & 1.65 & 1604.82 & 8.01 & 26.97 \\
\hline D6 & & 2.12 & 1811.30 & 10.31 & 51.68 \\
\hline D7 & -5.80 & 1.99 & 1570.91 & 9.36 & 41.18 \\
\hline E1 & -117.65 & 1.62 & 761.06 & 6.47 & 17.40 \\
\hline E2 & -97.96 & 1.60 & 695.09 & 6.89 & 19.58 \\
\hline E3 & 0 & 1.84 & 1735.86 & 9.08 & 37.09 \\
\hline E4 & 16.84 & 1.88 & 1191.50 & 8.43 & 32.34 \\
\hline E5 & -42.67 & 1.72 & 1619.92 & 8.26 & 29.45 \\
\hline E6 & & 2.10 & 1785.18 & 10.20 & 50.34 \\
\hline E7 & -5.80 & 1.85 & 1559.61 & 8.87 & 35.46 \\
\hline F1 & -117.65 & 1.47 & 822.49 & 6.18 & 14.89 \\
\hline $\mathrm{F} 2$ & -97.96 & 1.57 & 420.57 & 6.00 & 14.66 \\
\hline F3 & 0 & 1.88 & 1631.78 & 9.08 & 37.54 \\
\hline F4 & 16.84 & 1.91 & 1006.40 & 8.17 & 30.68 \\
\hline F5 & -42.67 & 1.72 & 1403.43 & 7.97 & 27.41 \\
\hline F6 & & 2.07 & 1705.67 & 9.98 & 47.81 \\
\hline F7 & -5.80 & 1.85 & 1523.89 & 8.82 & 35.05 \\
\hline G1 & -117.65 & 1.57 & 518.28 & 5.76 & 13.48 \\
\hline G2 & -97.96 & 1.55 & 546.24 & 6.35 & 16.29 \\
\hline G3 & 0 & 1.93 & 1589.30 & 9.19 & 39.04 \\
\hline G4 & 16.84 & 1.90 & 1089.55 & 8.31 & 31.59 \\
\hline G5 & -42.67 & 1.69 & 1477.63 & 7.98 & 27.15 \\
\hline G6 & & 2.06 & 1669.87 & 9.89 & 46.85 \\
\hline G7 & -5.80 & 1.91 & 1473.81 & 8.94 & 36.74 \\
\hline H1 & -117.65 & 1.71 & 531.72 & 6.14 & 16.20 \\
\hline $\mathrm{H} 2$ & -97.96 & 1.65 & 530.13 & 6.58 & 18.19 \\
\hline H3 & 0 & 1.85 & 1631.07 & 8.98 & 36.34 \\
\hline $\mathrm{H} 4$ & 16.84 & 1.95 & 1083.96 & 8.45 & 33.19 \\
\hline H5 & -42.67 & 1.69 & 1477.83 & 7.98 & 27.16 \\
\hline H6 & & 2.09 & 1670.52 & 9.99 & 48.23 \\
\hline H7 & -5.80 & 1.87 & 1498.18 & 8.85 & 35.51 \\
\hline RDX & -21.61 & $1.82^{\mathrm{a}}$ & $1590.72^{a}$ & $8.75^{\mathrm{a}}$ & $34.00^{\mathrm{a}}$ \\
\hline HMX & -21.61 & $1.91^{\mathrm{a}}$ & $1633.87^{\mathrm{a}}$ & $9.10^{\mathrm{a}}$ & $39.00^{\mathrm{a}}$ \\
\hline
\end{tabular}

a The experimental values were taken from Ref. ${ }^{47}$ 

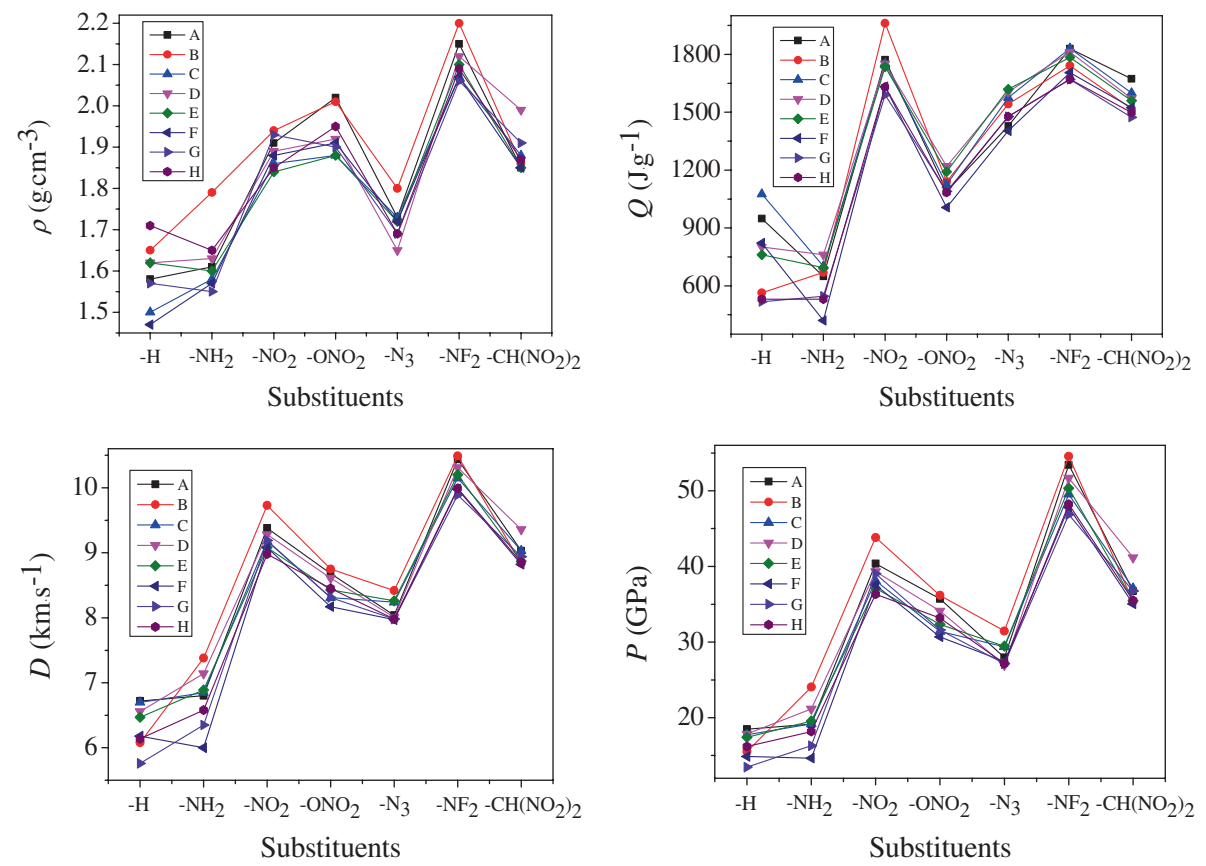

Figure 3. Comparison of the calculated $\rho, Q, D$ and $P$ values of triazole derivatives with different substituents.

\subsection{Thermal stability}

Studies on bond dissociation energies (BDEs) are important and essential to understand the stabilities and decomposition process of the high energetic compounds. Usually, the stronger are the weakest bonds, the more stable are the high energetic compounds; that is, the stability of the energetic compounds are directly relevant to bond strength, which is commonly described by bond dissociation energy. The possible initial steps in the decomposition process are considered for the triazole derivatives by breaking the following bonds: ring-bridge, ring- $\mathrm{NH}_{2}$, ring- $\mathrm{NO}_{2}$, ring- $\mathrm{ONO}_{2}$, ring $-\mathrm{N}_{3}$, ring $-\mathrm{NF}_{2}$, ring- $\mathrm{CH}\left(\mathrm{NO}_{2}\right)_{2}$, and $\mathrm{C}-\mathrm{NO}_{2}$ for $\mathrm{CH}\left(\mathrm{NO}_{2}\right)_{2}$ derivatives. The weakest bond among the same type of bonds is selected as the trigger bond.

The BDEs of relatively weak bonds of the triazole derivatives are listed in table 6. It was found that different substituents have different effects on the BDEs for the title compounds. For the A series, ring-bridge $\mathrm{N}-\mathrm{N}$ bonds of A1, A2, A3, A4, A5, A7 may be the trigger bond for initiation of the thermolysis process. The $\mathrm{N}-\mathrm{F}$ bond in the $-\mathrm{NF}_{2}$ substituted compound (A6) has smaller BDE value than that of corresponding ring-bridge $\mathrm{N}-\mathrm{N}$ bond. Therefore, we can infer that the trigger bond is $\mathrm{N}-\mathrm{F}$ in the $-\mathrm{NF}_{2}$ substituted compound. However, for the $\mathrm{B}$ series, ring- $\mathrm{NH}_{2}$, ring$\mathrm{NO}_{2}$, ring- $-\mathrm{ONO}_{2}$, ring- $\mathrm{N}_{3}$, ring $-\mathrm{NF}_{2}$, and $\mathrm{C}-\mathrm{N}$ bond in the $-\mathrm{CH}\left(\mathrm{NO}_{2}\right)_{2}$ substituted compound have smaller $\mathrm{BDE}$ values than that of corresponding ring-bridge $\mathrm{C}-$ $\mathrm{C}$ bonds. Moreover, this case is consistent with that of the $\mathrm{D}, \mathrm{E}, \mathrm{G}$, and $\mathrm{H}$ series. It is interesting to note that the $\mathrm{N}-\mathrm{NO}_{2}$ bond in $-\mathrm{NO}_{2}$ substituted compound (C3) and $\mathrm{C}-\mathrm{NO}_{2}$ bond in the $-\mathrm{CH}\left(\mathrm{NO}_{2}\right)_{2}$ substituted compound (C7) have a higher BDE than the $\mathrm{N}-\mathrm{N}$ bonds of ring-bridge. This also holds for the $\mathrm{F}$ series.

Obviously, the same substituent exerts diverse influences on the unsubstituted compound. For example, in the $\mathrm{B}, \mathrm{D}, \mathrm{E}, \mathrm{G}$, and $\mathrm{H}$ series, $-\mathrm{NF}_{2}$ group increases the $\mathrm{BDE}$ values, and the contribution to the $\mathrm{BDE}$ value is in the order of $\mathrm{B}>\mathrm{G}>\mathrm{H}>\mathrm{E}>\mathrm{D}$. Most of the weakest bonds in the triazole derivatives have a relatively high $\mathrm{BDE}$ values. Considering the practical requirements, a quantitative criteria associated stability (BDE of the trigger bond) requirements, i.e., $\mathrm{BDE} \approx 80-120 \mathrm{~kJ} \cdot \mathrm{mol}^{-1}{ }^{48}$ is proposed and recommended for potential energetic compounds. ${ }^{49}$ The calculated BDEs of triazole derivatives essentially satisfy this requirement obtained at the B3LYP/6-311G(d,p) level, which means that these compounds suffice the stability requirement of explosives.

As is well-known, a good nitrogen-rich high energetic compound not only has excellent detonation properties but also good stability. Considering the energetic properties and thermal stability, it can be concluded that series $\mathrm{A}\left(-\mathrm{NO}_{2},-\mathrm{NF}_{2},-\mathrm{CH}\left(\mathrm{NO}_{2}\right)_{2}\right)$, series $\mathrm{B}\left(-\mathrm{NO}_{2},-\mathrm{NF}_{2}\right)$, series $\mathrm{C}\left(-\mathrm{NO}_{2},-\mathrm{NF}_{2},-\mathrm{CH}\left(\mathrm{NO}_{2}\right)_{2}\right)$, series $\mathrm{D}\left(-\mathrm{NO}_{2},-\mathrm{NF}_{2},-\mathrm{CH}\left(\mathrm{NO}_{2}\right)_{2}\right)$, series $\mathrm{E}\left(-\mathrm{NO}_{2}\right.$, $\left.-\mathrm{NF}_{2}\right)$, series $\mathrm{F}\left(-\mathrm{NO}_{2},-\mathrm{NF}_{2}\right)$, series $\mathrm{G}\left(-\mathrm{NO}_{2},-\mathrm{NF}_{2}\right.$, $\left.-\mathrm{CH}\left(\mathrm{NO}_{2}\right)_{2}\right)$, and series $\mathrm{H}\left(-\mathrm{NO}_{2},-\mathrm{NF}_{2}\right)$ possess better energetic properties and thermal stabilities. Therefore, these 20 compounds can be considered as potential 
Table 6. Bond dissociation energies $\left(\mathrm{kJ} \cdot \mathrm{mol}^{-1}\right)$ of the relatively weak bonds of the triazole derivatives.

\begin{tabular}{|c|c|c|c|c|c|c|c|c|}
\hline Compd. & ring-bridge & ring- $\mathrm{NH}_{2}$ & ring- $\mathrm{NO}_{2}$ & ring- $\mathrm{ONO}_{2}$ & ring- $\mathrm{N}_{3}$ & ring- $\mathrm{NF}_{2}$ & ring- $\mathrm{CH}\left(\mathrm{NO}_{2}\right)_{2}$ & $\mathrm{C}-\mathrm{NO}_{2}$ \\
\hline A1 & 204.42 & & & & & & & \\
\hline A2 & 127.42 & 342.06 & & & & & & \\
\hline A3 & 98.18 & & 109.83 & & & & & \\
\hline A4 & 108.47 & & & 313.26 & & & & \\
\hline A5 & 117.76 & & & & 368.18 & & & \\
\hline A6 & 169.97 & & & & & 140.28 & & \\
\hline A7 & 81.46 & & & & & & 224.06 & 114.96 \\
\hline B1 & 544.14 & & & & & & & \\
\hline B2 & 462.64 & 85.50 & & & & & & \\
\hline B3 & 92.06 & & 87.81 & & & & & \\
\hline B4 & 496.46 & & & 103.67 & & & & \\
\hline B5 & 472.78 & & & & 170.73 & & & \\
\hline B6 & 466.63 & & & & & 150.49 & & \\
\hline B7 & 532.26 & & & & & & 326.77 & 116.15 \\
\hline $\mathrm{C} 1$ & 286.81 & & & & & & & \\
\hline $\mathrm{C} 2$ & 80.33 & 415.33 & & & & & & \\
\hline C3 & 267.63 & & 211.88 & & & & & \\
\hline $\mathrm{C} 4$ & 199.60 & & & 375.80 & & & & \\
\hline C5 & 90.82 & & & & 324.62 & & & \\
\hline C6 & 180.11 & & & & & 234.31 & & \\
\hline C7 & 273.45 & & & & & & 442.53 & 104.70 \\
\hline D1 & 532.64 & & & & & & & \\
\hline $\mathrm{D} 2$ & 535.81 & 147.40 & & & & & & \\
\hline D3 & 445.01 & & 162.84 & & & & & \\
\hline D4 & 520.51 & & & 123.44 & & & & \\
\hline D5 & 548.43 & & & & 136.73 & & & \\
\hline D6 & 486.96 & & & & & 95.44 & & \\
\hline D7 & 529.78 & & & & & & 356.39 & 104.96 \\
\hline E1 & 539.95 & & & & & & & \\
\hline E2 & 561.51 & 188.06 & & & & & & \\
\hline E3 & 511.27 & & 134.07 & & & & & \\
\hline E4 & 538.81 & & & 389.36 & & & & \\
\hline E5 & 522.96 & & & & 107.39 & & & \\
\hline E6 & 522.08 & & & & & 126.00 & & \\
\hline E7 & 512.48 & & & & & & 316.52 & 83.97 \\
\hline $\mathrm{F} 1$ & 298.48 & & & & & & & \\
\hline F2 & 80.65 & 436.04 & & & & & & \\
\hline F3 & 227.39 & & 191.00 & & & & & \\
\hline F4 & 126.56 & & & 377.47 & & & & \\
\hline F5 & 105.07 & & & & 354.73 & & & \\
\hline F6 & 172.42 & & & & & 229.97 & & \\
\hline F7 & 271.97 & & & & & & 434.05 & 116.27 \\
\hline G1 & 534.16 & & & & & & & \\
\hline G2 & 506.54 & 199.30 & & & & & & \\
\hline G3 & 465.46 & & 112.21 & & & & & \\
\hline G4 & 514.89 & & & 91.65 & & & & \\
\hline G5 & 510.62 & & & & 141.75 & & & \\
\hline G6 & 499.84 & & & & & 133.22 & & \\
\hline G7 & 524.24 & & & & & & 362.64 & 123.30 \\
\hline H1 & 509.67 & & & & & & & \\
\hline $\mathrm{H} 2$ & 522.42 & 221.18 & & & & & & \\
\hline H3 & 514.49 & & 110.81 & & & & & \\
\hline $\mathrm{H} 4$ & 504.96 & & & 162.72 & & & & \\
\hline H5 & 524.90 & & & & 141.49 & & & \\
\hline H6 & 523.16 & & & & & 129.87 & & \\
\hline H7 & 514.57 & & & & & & 341.24 & 108.53 \\
\hline
\end{tabular}


candidates for nitrogen-rich high energetic compounds with enhanced performance and reduced sensitivity.

\section{Conclusions}

In this study, systematic calculations have been performed on triazole-based compounds at the DFTB3LYP/6-311G(d,p) level. On the basis of the theoretical studies of the structures and the properties for the triazole derivatives, the following conclusions are drawn.

(1) The symmetry and hyperconjugation system existing in triazole derivatives have identical contribution to the stabilization. The HOMO and LUMO energy levels decrease when $-\mathrm{NO}_{2},-\mathrm{ONO}_{2},-\mathrm{NF}_{2}$, and $-\mathrm{CH}\left(\mathrm{NO}_{2}\right)_{2}$ groups are attached to the ring. The electron withdrawing groups break the $\pi$ electron cloud system, which increases the energies of triazole derivatives. However, because of the electron donating effect, the introduction of $-\mathrm{NH}_{2}$ group will make $E_{\text {HOMO }}$ and $E_{\text {LUMO }}$ increase gradually. This shows that the HOMO and LUMO energies are associated with the substituents in the parent ring.

(2) The calculated heats of formation in condensed phase show the same trend as the heats of formation in gas phase. Moreover, the substitution of $-\mathrm{N}_{3}$ plays a very important role in increasing the heats of formation in gas phase and in condensed phase of the derivatives, while the substitution of $-\mathrm{ONO}_{2}$ group greatly reduces the values. The energy-rich bonds in $-\mathrm{N}_{3}$ group release large amount of energy, which increases the heats of formation in gas phase and in condensed phase.

(3) Most of the substituents improve $\rho, D$, and $P$ values. The substitutions of $-\mathrm{NO}_{2}$ and especially $-\mathrm{NF}_{2}$ are very helpful for increasing the densities, detonation properties of the triazole derivatives. Calculated results of detonation velocities and detonation pressures for triazole derivatives indicate that series A (A3, A6), series B (B3, B6), series C (C3, C6), series D (D3, D6, D7), series E (E3, E6), series F (F3, F6), series G (G3, G6), and series $\mathrm{H}(\mathrm{H} 3, \mathrm{H} 6)$ satisfy the quantitative criteria for nitrogen-rich high energetic compounds.

(4) An analysis of the BDEs for several relatively weak bonds suggests that most of the triazole derivatives have good thermal stabilities. In addition, because of the inductive effect of different substituents, the thermal stabilities of the triazole derivatives decrease.

(5) Considering the energetic properties and thermal stability, series A $\left(-\mathrm{NO}_{2},-\mathrm{NF}_{2},-\mathrm{CH}\left(\mathrm{NO}_{2}\right)_{2}\right)$, series $\mathrm{B}\left(-\mathrm{NO}_{2},-\mathrm{NF}_{2}\right)$, series $\mathrm{C}\left(-\mathrm{NO}_{2},-\mathrm{NF}_{2},-\mathrm{CH}\left(\mathrm{NO}_{2}\right)_{2}\right)$, series $\mathrm{D}\left(-\mathrm{NO}_{2},-\mathrm{NF}_{2},-\mathrm{CH}\left(\mathrm{NO}_{2}\right)_{2}\right)$, series $\mathrm{E}\left(-\mathrm{NO}_{2}\right.$, $\left.-\mathrm{NF}_{2}\right)$, series $\mathrm{F}\left(-\mathrm{NO}_{2},-\mathrm{NF}_{2}\right)$, series $\mathrm{G}\left(-\mathrm{NO}_{2},-\mathrm{NF}_{2}\right.$,
$\left.-\mathrm{CH}\left(\mathrm{NO}_{2}\right)_{2}\right)$, and series $\mathrm{H}\left(-\mathrm{NO}_{2},-\mathrm{NF}_{2}\right)$ can be considered as potential candidates for nitrogen-rich triazole-based high energetic compounds with higher performance and thermal stability. These results provide theoretical support for molecular design and experimental synthesis of novel triazole-based high energetic compounds.

\section{Acknowledgments}

This work was supported by the Scientific and Technologial Innovation Programs of Higher Education Institutions in Shanxi and Natural Science Foundation of Shanxi Normal University (Grant No. ZR1504).

\section{References}

1. Klapotke T M and Witkowski T G 2015 Propell. Explos. Pyrot. 40366

2. Fischer D, Klapotke T M and Stierstorfer J 2015 Angew. Chem. Int. Ed. 5410299

3. Yedukondalu N and Vaitheeswaran G $2015 \mathrm{~J}$. Chem. Phys. 143064508

4. Wei H, He C L, Zhang J H and Shreeve J M 2015 Angew. Chem. Int. Ed. $\mathbf{5 4} 9367$

5. Piercey D G, Chavez D E, Heimsch S, Kirst C, Klapotke T M and Stierstorfer J 2015 Propell. Explos. Pyrot. 40491

6. Wu J T, Zhang J G, Yin X, Cheng Z Y and Xu C X 2015 New J. Chem. 395265

7. Klapotke T M, Schmid P C, Schnell S and Stierstorfer J 2015 J. Mater. Chem. A 32658

8. Guo Y X, Feng X, Han T Y, Wang S, Lin Z G, Dong Y P and Wang B 2014 J. Am. Chem. Soc. 13615485

9. Becuwe A and Delclos A 1989 Proceedings of the Ninth International Symposium on Detonation (Arlington, VA: Office of the Chief of Naval Research) pp. 1008-1013

10. Singh G, Kapoor I P S, Tiwari S K and Felix P S 2001 J. Hazard. Mater. 8167

11. Lee J S and Jaw K S 2006 J. Therm. Anal. Calorim. 85463

12. Dippold A A, Klapotke T M, Martin F A and Wiedbrauk S 2012 Eur. J. Inorg. Chem. 2429

13. Watenberg C, Charrne P and Laval F 1995 Propell. Explos. Pyrot. 2023

14. Tang Y X, Gao H X, Parrish D A and Shreeve J M 2015 Chem. Eur. J. 2111401

15. Wu Q, Zhu W H and Xiao H M 2014 J. Mol. Model. 202441

16. Tang Y X, Yang H W, Wu B, Ju X H, Lv C X and Cheng G B 2013 Angew. Chem. Int. Ed. 521

17. Klapotke T M, Schmid P C, Schnell S and Stierstorfer J 2015 Chem. Eur. J. 219219

18. Bian C M, Wang K, Liang L X, Zhang M, Li C and Zhou Z M 2014 Eur. J. Inorg. Chem. 6022

19. Srinivas D, Ghule V D and Muralidharan K 2014 RSC Adv. 47041

20. He $\mathrm{P}$, Zhang $\mathrm{J} \mathrm{G}$, Wang $\mathrm{K}$, Yin $\mathrm{X}$, Jin $\mathrm{X}$ and Zhang $\mathrm{T} \mathrm{L}$ 2015 Phys. Chem. Chem. Phys. 175840

21. Li X H and Zhang R Z 2014 J. Chem. Sci. 1261753 
22. Zhao G Z and Lu M 2013 J. Mol. Model. 193403

23. Singh R, Singh H J and Sengupta S K 2015 J. Chem. Sci. 1271099

24. Frisch M J, Trucks G W, Schlegel H B, Scuseria G E, Robb M A, Cheeseman J R, Scalmani G, Barone V, Mennucci B, Petersson G A, Nakatsuji H, Caricato M, Li X, Hratchian H P, Izmaylov A F, Bloino J, Zheng G, Sonnenberg J L, Hada M, Ehara M, Toyota K, Fukuda R, Hasegawa J, Ishida M, Nakajima T, Honda Y, Kitao O, Nakai H, Vreven T, Montgomery J A, Peralta J E, Ogliaro F, Bearpark M, Heyd J J, Brothers E, Kudin K N, Staroverov V N, Keith T, Kobayashi R, Normand J, Raghavachari K, Rendell A, Burant J C, Iyengar S S, Tomasi J, Cossi M, Rega N, Millam J M, Klene M, Knox J E, Cross J B, Bakken V, Adamo C, Jaramillo J, Gomperts R, Stratmann R E, Yazyev O, Austin A J, Cammi R, Pomelli C, Ochterski J W, Martin R L, Morokuma K, Zakrzewski V G, Voth G A, Salvador P, Dannenberg J J, Dapprich S, Daniels A D, Farkas O, Foresman J B, Ortiz J V, Cioslowski J and Fox D J 2010 Gaussian 09, Revision C. 01 (Wallingford, CT: Gaussian Inc.)

25. Politzer P, Martinez J, Murray J S, Concha M C and Toro-Labbé A 2009 Mol. Phys. 1072095

26. Becke A D 1992 J. Chem. Phys. 979173

27. Lee C, Yang W and Parr R G 1988 Phys. Rev. B 37785

28. Zhao G Z and Lu M 2013 Struct. Chem. 24139

29. Vo T T, Zhang J H, Parrish D A, Twamley B and Shreeve J M 2013 J. Am. Chem. Soc. 13511787

30. Atkins P W 1982 In Physical Chemistry 2nd ed. (Oxford: Oxford University Press)

31. Rice B M, Pai S V and Hare J 1999 Combust. Flame 118 445

32. Politzer P, Lane P and Murray J S 2011 Cent. Eur. J. Energetic Mater. 839
33. Politzer P, Ma Y, Lane P and Concha M C 2005 Int. J. Quantum Chem. 105341

34. Kamlet M J and Jacobs S J 1968 J. Chem. Phys. 4823

35. Zhang X H and Yun Z H 1989 In Explosive Chemistry (Beijing: National Defence Industry Press)

36. Liu H, Wang F, Wang G X and Gong X D $2012 \mathrm{~J}$. Comput. Chem. 331790

37. Li J S 2010 J. Phys. Chem. B 1142198

38. Cao X Z, Song T Y and Wang X Q 1987 In Inorganic Chemistry (Beijing: Higher Education Press)

39. Scott A P and Radom L 1996 J. Phys. Chem. 10016502

40. Dean J A 1999 In Lange's Handbook of Chemistry 15th ed. (New York: McGraw-Hill)

41. David R L 2003-2004 In Handbook of Chemistry and Physics 84th ed. (Boca Raton: CRC Press)

42. Afeefy H Y, Liebman J F and Stein S E 2000 NIST Chemistry WebBook: NIST Standard Reference Database Number 69 (Gaithersburg: National Institute of Standards and Technology)

43. Yong P, Zhu W H and Xiao H M 2012 J. Mol. Model. 183125

44. Wei T, Zhang J J, Zhu W H, Zhang X W and Xiao H M 2010 J. Struct. Chem.: (THEOCHEM) 95655

45. Huynh M H V, Hiskey M A, Chavez D E, Naud D L and Gilardi R D 2005 J. Am. Chem. Soc. 12712537

46. Chavez D E, Hiskey M A and Gilardi R D 2000 Angew. Chem. Int. Ed. 391791

47. Talawar M B, Sivabalan R, Mukundan T, Muthurajan H, Sikder A K, Gandhe B R and Subhananda R 2009 J. Hazard. Mater. 161589

48. Chung G, Schmidt M W and Gordon M S 2000 J. Phys. Chem. A 1045647

49. Xiao H M, Xu X J and Qiu L 2008 In Theoretical Design of High Energy Density Materials (Beijing: Science Press) 